\title{
ANALYSIS OF YELLOWFIN TUNA (Thunnus albacares) FISHING GROUND BASED ON SEA SURFACE TEMPERATURE AND CHLOROPHYLL-A IN THE WEST SUMATERA WATERS
}

\author{
Ridwan Habibullah $^{1 *}$, Mubarak ${ }^{2}$, Musrifin Galib ${ }^{2}$ \\ ${ }^{1}$ Student of the Faculty of Fisheries and Marine Universitas Riau, Pekanbaru \\ ${ }^{2}$ Lecturer at the Faculty of Fisheries and Marine Universitas Riau, Pekanbaru \\ *ridwan.habibullah96@gmail.com
}

\begin{abstract}
This research was conducted on September 2019 in west Sumatera waters which was aimed to find out the level of aquatic productivity, to analyze the yellowfin tuna fishing ground and to find out the corelation between sea surface temperature (SST) and chlorophylla with the total catch of yellowfin tuna. In conducting the research, survey and spatial analyze were used as the method. The highest total catch of yellowfin tuna was on October 2019 with the total $60.610 \mathrm{~kg}$ and the CPUE $166 \mathrm{~kg} /$ trip. On the other hand, the lowest total catch was on June with the total $18.080 \mathrm{~kg}$ and CPUE $92,7179 \mathrm{~kg} / \mathrm{trip}$. Based on the result of the CPUE, October is the best month for fishing. The correlation coefficient between SST and total catch in 2018 was -0.69 which mean there was a negative correlation. Meanwhile, the correlation chlorophyll-a with the total catch was 0.65 which mean the corelation between both variables were not good.
\end{abstract}

Keywords: Aquatic productivity, sea surface temperature, chlorophyll-a, yellowfin tuna total catch

\section{PENDAHULUAN}

Penangkapan ikan yellowfin tuna di perairan barat Sumatera terus mengalami peningkatan, hal ini didukung dengan adanya Pelabuhan Perikanan Samudera (PPS) Bungus yang menjadi pusat kegiatan perikanan tuna di perairan Sumatera Barat. PPS Bungus merupakan kawasan industrialisasi perikanan tangkap yang mengacu pada perikanan Tuna, Tongkol dan Cakalang atau dengan istilah TTC. Peningkatan tingkat tangkapan dapat dilakukan dengan menambah jumlah armada/unit dan trip penangkapan. Jumlah trip dapat ditingkatkan jika penyebaran daerah penangkapan telah diprediksi sebelum kegiatan operasi penangkapan dilakukan. Jika prediksi daerah penangkapan sebelum operasi penangkapan dilakukan, maka efisiensi dan efektifitas akan tercapai.

Penentuan daerah penangkapan ikan di perairan Indonesia umumnya masih menggunakan cara-cara tradisional dengan cara memburu (hunting) gerombolan ikan, sehingga upaya penangkapan ikan kurang efektif dan efisien. Tingkat ketidakpastian hasil tangkapan cukup tinggi, karena nelayan tidak mengetahui lokasi yang potensial untuk penangkapan ikan. Mereka menentukan daerah penangkapan ikan hanya berdasarkan pengalaman atau melihat tanda-tanda alam.

Usaha untuk memprediksi daerah penangkapan ikan (fishing ground) dapat dilakukan melalui pendekatan suhu permukaan laut (SPL) dan klorofil-a. Hampir semua populasi ikan yang hidup di 
perairan laut mempunyai kisaran suhu dan klorofil-a yang optimum untuk kehidupannya.

Penelitian ini bertujuan untuk mengetahui tingkat produktivitas perairan, menganalisis daerah tangkapan yellowfin tuna serta menganalisis hubungan SPL dan klorofil-a dengan hasil tangkapan yellowfin tuna di perairan Sumatera Barat. Diharapkan dari penelitian ini mampu memberikan informasi kepada nelayan tangkap serta pihak lainnya mengenai daerah penangkapan yellowfin tuna yang potensial di perairan laut Sumatera Barat.

\section{METODE PENELITIAN Waktu dan Tempat}

Penelitian ini telah dilaksanakan pada bulan September 2019 di perairan Sumatera Barat. Dilanjutkan dengan pengolahan data lapangan dan data citra satelit Aqua MODIS yang di download pada bulan September-November 2019 di Loka Riset Sumber Daya dan Kerentanan Pesisir (LRSDKP), Bungus.

\section{Metode Penelitian}

\section{Prosedur Penelitian}

Data upaya penangkapan dari hasil penangkapan selama 1 tahun dapat dihitung nilai (catch per unit effort / CPUE). Menurut Noija et al., (2014), rumus yang digunakan adalah sebagai berikut:

Keterangan :

$$
C P U E i=\frac{C i}{F i}
$$

$$
\begin{aligned}
& C P U E_{i}=\text { Hasil tangkapan per upaya } \\
& C i=\text { Hasil tangkapan ke-i }(\mathrm{kg}) \\
& F i \quad=\text { Upaya penangkapan ke-I } \\
& \text { (trip) }
\end{aligned}
$$

Untuk mengetahui hubungan SPL dengan hasil tangkapan dilakukan analisis korelasi. Adapun rumus koefisien korelasi sederhana sebagai berikut (Walpole 1995): Koefisien korelasi (r)
Penelitian ini menggunakan metode survei dan analisis keruangan (spasial). Data yang digunakan adalah berupa data primer dan sekunder. Data primer yang dibutuhkan adalah data SPL, salinitas, $\mathrm{pH}$ serta data hasil tangkapan yellowfin tuna. Data sekunder lain yang dikumpulkan adalah kondisi umum perikanan di lokasi penelitian seperti data tangkapan tahunan, unit penangkapan dan posisi penangkapan. Data tersebut diperoleh dari PPS Bungus dan studi literatur. Metode analisis keruangan digunakan untuk menganalisa secara visual data citra satelit Aqua MODIS yang telah di proses untuk mendapatkan sebaran SPL dan klorofil-a di perairan Sumatera Barat.

Untuk mendapatkan sebaran SPL di perairan Sumatera Barat dilakukan menggunakan citra Aqua MODIS yang telah didownload melalui web https://oceancolor.gsfc.nasa.gov/,

sedangkan pengukuran suhu di lapangan dilakukan menggunakan thermometer. Sebaran klorofil-a diketahui dengan melakukan analisis terhadap citra Aqua MODIS.

$$
\mathrm{r}=\frac{n\left(\sum X Y\right)-\left(\sum X\right)\left(\sum Y\right)}{\sqrt{\left[n\left(\sum X^{2}\right)-\left(\sum X\right)^{2}\right]\left[n\left(\sum Y^{2}\right)-\left(\sum Y\right)^{2}\right]}}
$$

Keterangan :

$n=$ Banyaknya Pasangan data $\mathrm{X}$ dan Y

$\Sigma x=$ Total Jumlah dari Variabel $\mathrm{X}$

$\Sigma y=$ Total Jumlah dari Variabel $\mathrm{Y}$

$\Sigma x^{2}=$ Kuadrat dari Total Jumlah Variabel X

$\Sigma y^{2}=$ Kuadrat dari Total Jumlah Variabel Y

$\Sigma x y=$ Hasil Perkalian dari Total Jumlah Variabel X dan Variabel Y

Nilai koefisien korelasi $\mathrm{r}$ berkisar -1 $\leq \mathrm{r} \leq+1$. Korelasi erat jika $\mathrm{r} \geq 0,7$ dan $\mathrm{r} \leq$ 0,6 dan korelasi tidak erat jika $-0,6<\mathrm{r}<$ 0,7 (Lind et al, 2000). 
Penentuan daerah penangkapan ikan potensial ditentukan berdasarkan dari jumlah hasil tangkapan serta sebaran SPL dan klorofil-a pada daerah penangkapan. Penilaian jumlah hasil tangkapan dilakukan berdasarkan pendekatan CPUE selama 1 tahun.

Tabel 1. Kriteria Kelayakan Hasil Tangkapan Berdasarkan Ukuran Panjang Ikan Tuna

\begin{tabular}{cc}
\hline $\begin{array}{c}\text { Ukuran panjang } \\
(\mathrm{cm})\end{array}$ & Penilaian \\
\hline $\mathrm{x} \leq 49 \mathrm{~cm}$ & Tidak Layak Tangkap \\
$\mathrm{x} \geq 50 \mathrm{~cm}$ & Layak Tangkap \\
\hline Sumber: Kantun et al., (2014)
\end{tabular}

Tabel 2. Penilaian Jumlah Hasil Tangkapan

\begin{tabular}{cc}
$\begin{array}{c}\text { Jumlah Hasil Tangkapan } \\
(\mathrm{kg})\end{array}$ & Penilaian \\
\hline$\leq 200 \mathrm{~kg}$ & Sedikit \\
$200 \mathrm{~kg} \leq \mathrm{HT} \leq 400 \mathrm{~kg}$ & Sedang \\
$\geq 400 \mathrm{~kg}$ & Banyak \\
\hline
\end{tabular}

Sumber: Basuma, (2009)

\section{HASIL DAN PEMBAHASAN}

Kondisi Umum Daerah Penangkapan

Daerah Penangkapan Ikan Tuna yang dilakukan pada penelitian ini berada pada posisi $1^{\circ} 21^{\prime} 20.22$ " $-2^{\circ} 22$ ' 14.7 'LS dan $99^{\circ} 20^{\prime} 38.16^{\prime \prime}-100^{\circ} 4$ ' 26.10”BT.

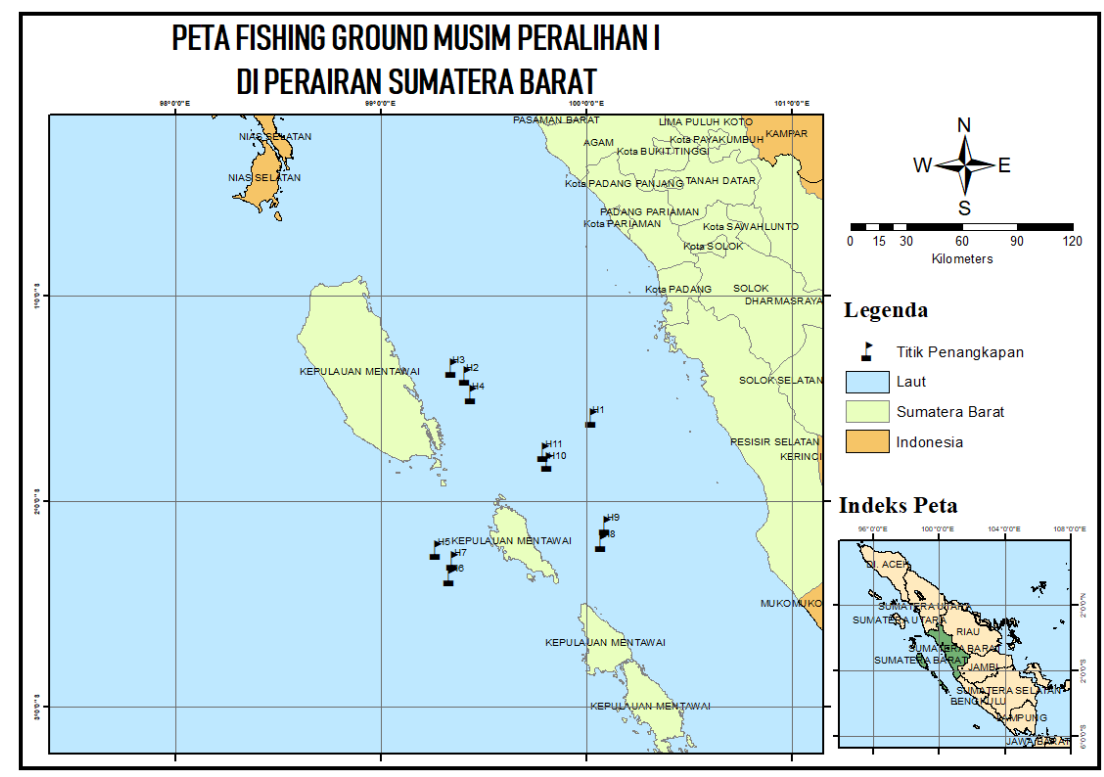

Gambar 1. Posisi Penangkapan Yellowfin Tuna

Kualitas Perairan Penangkapan dan Jumlah Tangkapan

Pengukuran data kualitas perairan di lapangan dan jumlah hasil tangkapan di 11 titik penangkapan dapat dilihat pada Tabel 3.

\section{Sebaran Suhu Permukaan Laut}

Analisis visual citra sebaran SPL bulan Januari-Desember tahun 2018 menunjukkan perbedaan nilai SPL untuk setiap bulannya. Secara umum sebaran rata- rata SPL perairan Sumatera Barat cenderung mengalami fluktuasi yang berbeda-beda pada setiap musimnya. Perairan dekat pesisir cenderung memiliki suhu yang lebih tinggi dibandingkan perairan lepas pantai atau jauh dari pesisir. Menurut Ilahude (1997) pengaruh daratan yang kuat terhadap suhu perairan menyebabkan perairan pantai mempunyai suhu yang lebih tinggi dibandingkan perairan lepas pantai. 
Tabel 3. Kualitas Perairan Penangkapan dan Jumlah Tangkapan

\begin{tabular}{|c|c|c|c|c|c|c|c|c|}
\hline \multirow{2}{*}{ Hari } & \multirow{2}{*}{ Waktu } & \multicolumn{2}{|c|}{ Posisi Penangkapan } & \multirow{2}{*}{$\begin{array}{c}\text { Suhu } \\
\left({ }^{\circ} \mathrm{C}\right)\end{array}$} & \multirow{2}{*}{$\begin{array}{l}\text { Salinitas } \\
\text { (ppt) }\end{array}$} & \multirow{2}{*}{$\mathrm{pH}$} & \multirow{2}{*}{$\begin{array}{c}\text { Berat } \\
(\mathrm{kg})\end{array}$} & \multirow{2}{*}{$\begin{array}{r}\text { Tota } \\
(\mathrm{kg})\end{array}$} \\
\hline & & Longitude & Latitude & & & & & \\
\hline 1 & $\begin{array}{l}12 / 09 / 2019 \\
\text { Pukul } 18.06\end{array}$ & 100.156389 & -1.7825 & 29 & 30 & 6 & - & 0 \\
\hline 2 & $\begin{array}{c}13 / 09 / 2019 \\
\text { Pukul 17.20 }\end{array}$ & 99.5777778 & -1.55444 & 28 & 29 & 8 & 32 & 32 \\
\hline 3 & $\begin{array}{l}14 / 09 / 2019 \\
\text { Pukul } 17.16\end{array}$ & 99.51 & -1.44361 & 27 & 30 & 7 & - & 0 \\
\hline 4 & $\begin{array}{l}15 / 09 / 2019 \\
\text { Pukul } 16.57\end{array}$ & 99.5438889 & -1.735 & 27 & 32 & 8 & - & 0 \\
\hline 5 & $\begin{array}{c}\text { 16/09/2019 } \\
\text { Pukul } 18.10\end{array}$ & 99.3247222 & -2.32944 & 28 & 33 & 8 & $\begin{array}{l}15 \\
70\end{array}$ & 85 \\
\hline 6 & $\begin{array}{l}17 / 09 / 2019 \\
\text { Pukul } 18.47\end{array}$ & 99.3772222 & -2.435 & 27 & 32 & 7 & $\begin{array}{l}33 \\
33 \\
51\end{array}$ & 117 \\
\hline 7 & $\begin{array}{c}18 / 09 / 2019 \\
\text { Pukul } 18.10\end{array}$ & 99.3558333 & -2.46472 & 27 & 32 & 7 & 43 & 43 \\
\hline 8 & $\begin{array}{c}\text { 19/09/2019 } \\
\text { Pukul 18.45 }\end{array}$ & 100.1875 & -2.21472 & 27 & 31 & 7 & $\begin{array}{l}55 \\
33 \\
43 \\
68 \\
21 \\
67\end{array}$ & 287 \\
\hline 9 & $\begin{array}{l}\text { 20/09/2019 } \\
\text { Pukul } 17.47\end{array}$ & 100.237778 & -2.21083 & 27 & 31 & 7 & - & 0 \\
\hline 10 & $\begin{array}{l}21 / 09 / 2019 \\
\text { Pukul } 18.24\end{array}$ & 99.9783333 & -2.01639 & 27 & 32 & 7 & $\begin{array}{l}75 \\
75 \\
68\end{array}$ & 218 \\
\hline 11 & $\begin{array}{l}22 / 09 / 2019 \\
\text { Pukul } 18.00\end{array}$ & 99.8961111 & -2.00194 & 26 & 30 & 6 & 23 & 23 \\
\hline
\end{tabular}

Tabel 4. Kisaran Suhu Permukaan Laut $\left({ }^{\circ} \mathrm{C}\right)$ Tahun 2018

\begin{tabular}{cccc}
\hline \multirow{2}{*}{ No } & Bulan & \multirow{2}{*}{ Musim } & Suhu Permukaan Laut $\left({ }^{\circ} \mathrm{C}\right)$ \\
\cline { 3 - 3 } 1 & Januari & \multirow{2}{*}{ Barat } & $25,850-33,350$ \\
2 & Februari & & $27,905-32,585$ \\
3 & Maret & \multirow{2}{*}{ Peralihan I } & $27,150-33,485$ \\
4 & April & & $27,305-32,935$ \\
5 & Mei & & $27,895-32,505$ \\
6 & Juni & Timur & $28,085-32,575$ \\
7 & Juli & & $26,885-32,475$ \\
8 & Agustus & & $27,615-31,990$ \\
9 & September & \multirow{2}{*}{ Peralihan II } & $26,975-31,610$ \\
10 & Oktober & & $26,730-32,150$ \\
11 & November & Barat & $27,505-34,285$ \\
12 & Desember & & $27,350-32,585$ \\
\hline
\end{tabular}

Sebaran Suhu Permukaan Laut Musim Barat

Musim Barat (Gambar 2) sebaran SPL setiap bulannya mengalami perubahan dimana pada Bulan Desember dan Februari umumnya suhu perairan yang tinggi berada di sepanjang pesisir pantai Sumatera Barat, akan tetapi pada Bulan Januari sebaran 
suhu mengalami perubahan dimana dikawasan pesisir pantai umumnya memiliki suhu yang relatif dingin. Berdasarkan Nontji (2007), setiap Bulan
November hingga Januari di Indonesia, terutama bagian barat sedang mengalami musim hujan dengan curah hujan yang cukup tinggi.
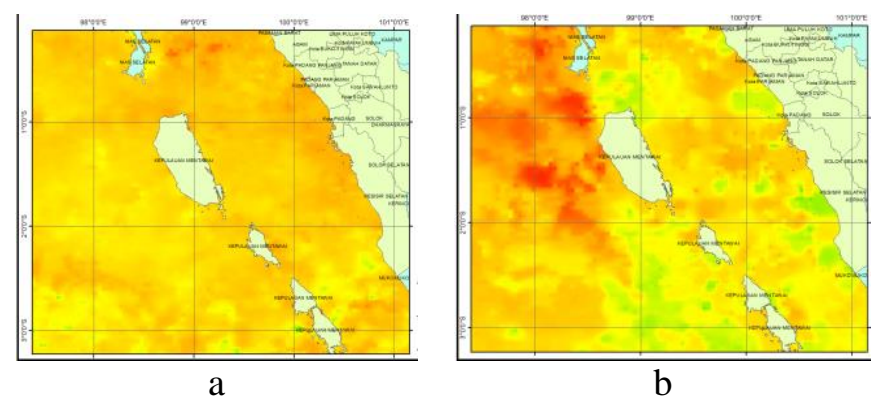
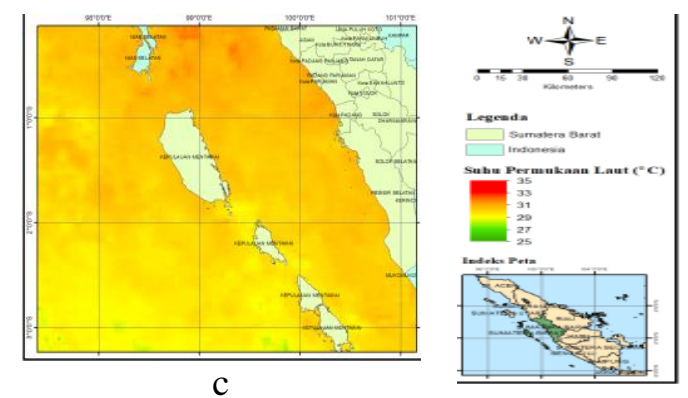

Gambar 2. Sebaran Suhu Permukaan Laut Musim Barat. (a) Sebaran Suhu Permukaan Laut Bulan Desember, (b) Sebaran Suhu Permukaan Laut Bulan Januari, (c) Sebaran Suhu Permukaan Laut Bulan Februari.

Sebaran Suhu Permukaan Laut Musim Peralihan I

SPL pada Musim Peralihan I (Gambar 3) mengalami fluktusi suhu yang tidak terlalu tinggi. Penyebaran suhu lebih merata di seluruh wilayah perairan dikarenakan akan berakhirnya Musim Barat menuju Musim Timur yang akan mendapatkan intensitas cahaya matahari lebih banyak dibandingkan Musim Barat.

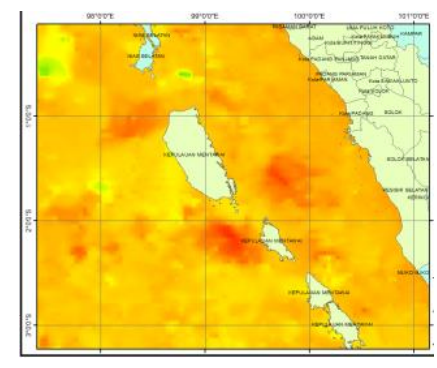

a

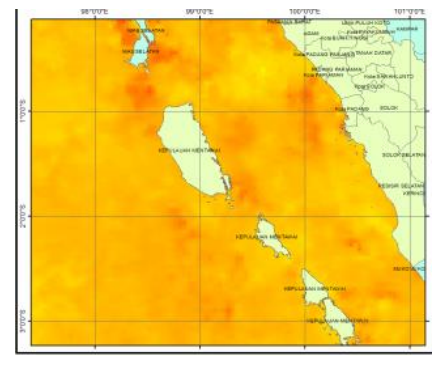

b

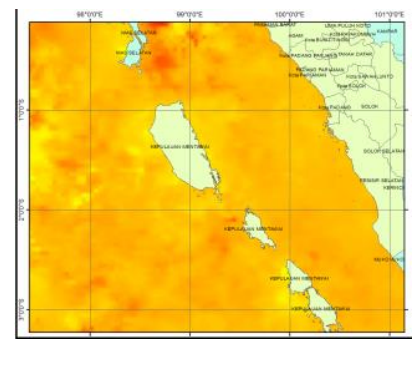

c

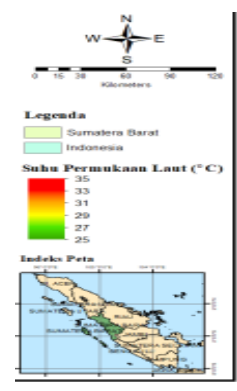

Gambar 3. Sebaran Suhu Permukaan Laut Musim Peralihan I. (a) Sebaran Suhu Permukaan Laut Bulan Maret, (b) Sebaran Suhu Permukaan Laut Bulan April, (c) Sebaran Suhu Permukaan Laut Bulan Mei.

Sebaran Suhu Permukaan Laut Musim Timur

Penyebaran suhu pada Musim Timur (Gambar 4) relatif merata di seluruh wilayah perairan Sumatera Barat. Hal ini diindikasikan bahwa pada Musim Timur perairan lebih banyak mendapatkan asupan cahaya matahari dibandingkan dengan musim-musim lainnya. Menurut Triatmodjo (2008) pada Musim Timur di belahan bumi utara mengalami Musim
Panas sedangkan belahan bumi selatan Musim Dingin dengan tekanan udara yang rendah, sehingga angin dari daratan Australia berhembus menuju Asia. Musim timur pola sirkulasi angin permukaan bergerak dari belahan bumi selatan menuju belahan bumi utara, pada periode ini sebahan SPL di perairan cukup hangat di karenakan angin yang berhembus membawa udara yang kering dari daratan Australia (Mubarak et al., 2015). 


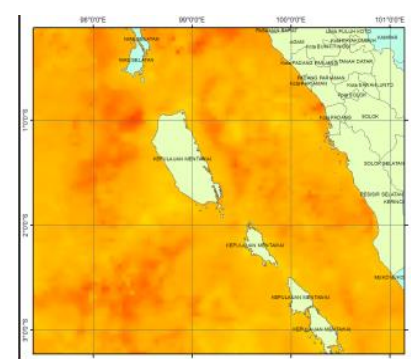

a

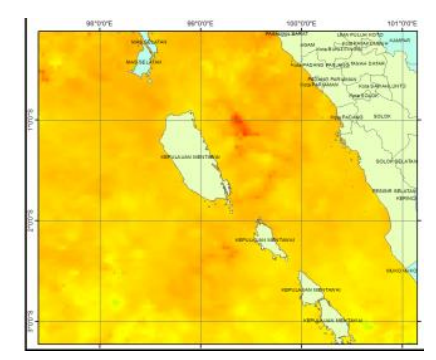

b

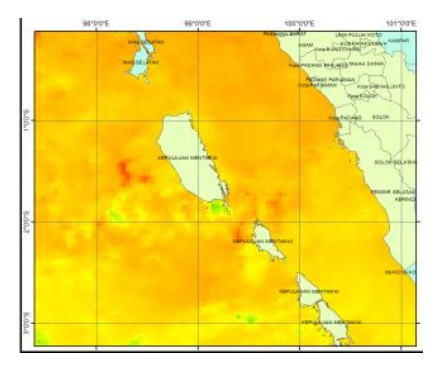

c

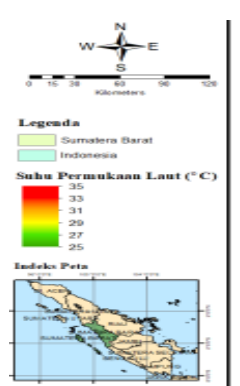

Gambar 4. Sebaran Suhu Permukaan Laut Musim Timur. (a) Sebaran Suhu Permukaan Laut Bulan Juni, (b) Sebaran Suhu Permukaan Laut Bulan Juli, (c) Sebaran Suhu Permukaan Laut Bulan Agustus.

\section{Sebaran Suhu Permukaan Laut Musim Peralihan II}

Musim Peralihan II merupakan peralihan antara Musim Timur ke Musim Barat. Pada musim ini masih mendapat pengaruh dari Musim Timur dengan

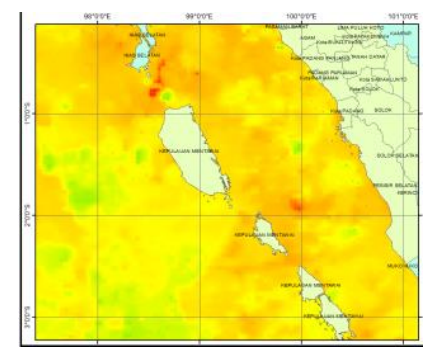

a

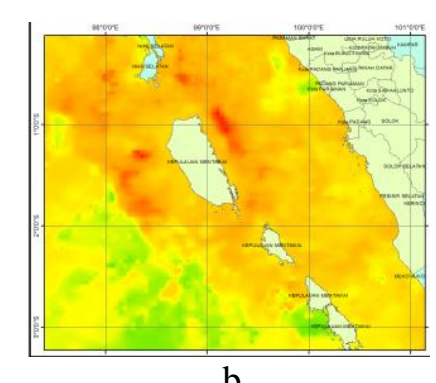

b penyinaran matahari yang sudah mulai berkurang dan menuju ke musim penghujan. Pada Gambar 5 menunjukkan sebaran suhu relatif turun dibandingkan musim sebelumnya.

Gambar 5. Sebaran Suhu Permukaan Laut Musim Peralihan II. (a) Sebaran Suhu Permukaan Laut Bulan September, (b) Sebaran Suhu Permukaan Laut Bulan Oktober, (c) Sebaran Suhu Permukaan Laut Bulan November.

\section{Sebaran Klorofil-a}

Jika ditinjau dari sebaran klorofil-a setiap bulannya yang dianalisis dari citra satelit Aqua MODIS level 3 pada tahun 2018, rata-rata konsentrasi klorofil-a paling tinggi terdapat pada Bulan November yaitu $1,523 \mathrm{mg} / \mathrm{m}^{3}$ dan bulan yang memiliki ratarata konsentrasi klorofil-a paling rendah yaitu Bulan Januari bernilai $0,303 \mathrm{mg} / \mathrm{m}^{3}$.

Pada setiap musim konsentrasi klorofil-a cendrung tinggi di sekitar pesisir pantai, hal tersebut dipengaruhi oleh run off bahan organik yang dibawa sejumlah aliran sungai yang kaya akan nutrien dari daratan ke pesisir pantai sehingga nilai konsentrasi klorofil pada pesisir bernilai tinggi. Hal ini sesuai dengan pendapat (Rasyid dan
Ibrahim, 2013) yang menyatakan bahwa sebaran klorofil-a lebih tinggi di perairan pantai dan pesisir sementara pada perairan lepas pantai cenderung lebih rendah. Tingginya sebaran konsentrasi klorofil-a di perairan pesisir dan pantai dipengaruhi oleh suplai nutrien dalam jumlah besar melalui run off dari daratan, sementara rendahnya konsentrasi klorofil-a di perairan lepas pantai karena tidak adanya suplai nutrien dari daratan secara langsung. Hutabarat (2006) mengatakan, fitoplankton hanya dapat dijumpai pada lapisan permukaan laut dengan intensitas cahaya matahari yang cukup dan tersedianya bahan-bahan organik. 
Tabel 5. Konsentrasi Klorofil-a $\left(\mathrm{mg} / \mathrm{m}^{3}\right)$ Tahun 2018

\begin{tabular}{|c|c|c|c|}
\hline \multirow{2}{*}{ No } & \multirow{2}{*}{ Bulan } & \multirow{2}{*}{ Musim } & Klorofil-a $\left(\mathrm{mg} / \mathrm{m}^{3}\right)$ \\
\hline & & & Kisaran \\
\hline 1 & Januari & \multirow{3}{*}{ Barat } & $0,1-1,25$ \\
\hline 2 & Februari & & $0,1-2,80$ \\
\hline 3 & Maret & & $0,05-2,20$ \\
\hline 4 & April & \multirow[t]{3}{*}{ Peralihan I } & $0,1-5,40$ \\
\hline 5 & Mei & & $0,1-3,05$ \\
\hline 6 & Juni & & $0,1-3,25$ \\
\hline 7 & Juli & \multirow[t]{3}{*}{ Timur } & $0,1-4,25$ \\
\hline 8 & Agustus & & $0,05-4,30$ \\
\hline 9 & September & & $0,1-2,95$ \\
\hline 10 & Oktober & \multirow[t]{2}{*}{ Peralihan II } & $0,1-9,00$ \\
\hline 11 & November & & $0,1-10,20$ \\
\hline 12 & Desember & Barat & $0,1-3,00$ \\
\hline
\end{tabular}

\section{Sebaran Konsentrasi Klorofil-a Musim Barat}

Gambar 6 merupakan sebaran interpolasi konsentrasi klorofil-a pada Musim Barat (Desember-Februari) 2018. Gambar 6a merupakan sebaran konsentrasi klorofil-a pada bulan Desember, konsentrasi klorofil-a yang didapat dari citra berkisar antara $0,1-3,00 \mathrm{mg} / \mathrm{m}^{3}$

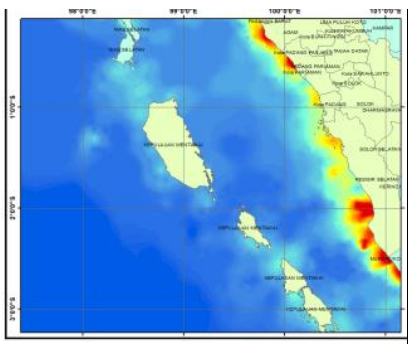

a

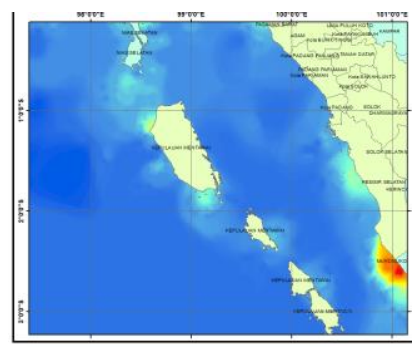

b

dengan rata-rata $0,686 \mathrm{mg} / \mathrm{m}^{3}$. Gambar $6 \mathrm{~b}$ merupakan konsentrasi klorofil-a bulan Januari yang berkisar antara $0,1-1,25$ $\mathrm{mg} / \mathrm{m}^{3}$ dengan rata-rata $0,303 \mathrm{mg} / \mathrm{m}^{3}$. Gambar 6c merupakan bulan terakhir Musim Barat yaitu bulan Februari. Konsentrasi klorofil-a yang didapat dari citra berkisar antara $0,1-2,80 \mathrm{mg} / \mathrm{m}^{3}$ dengan rata-rata $0,403 \mathrm{mg} / \mathrm{m}^{3}$.

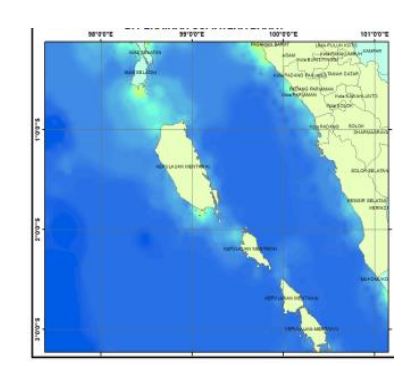

C

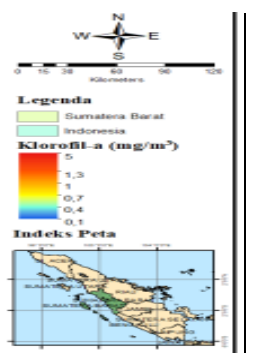

Gambar 6. Sebaran Klorofil-a Musim Barat. (a) Sebaran Klorofil-a Bulan Desember, (b) Sebaran Klorofil-a Bulan Januari, (c) Sebaran Klorofil-a Bulan Februari.

\section{Sebaran Konsentrasi Klorofil-a Musim Peralihan I}

Gambar 7 merupakan sebaran konsentrasi klorofil-a pada Musim Peralihan I (Maret-Mei) 2018. Gambar 7a merupakan sebaran konsentrasi klorofil-a pada bulan Maret dengan sebaran konsentrasi klorofil-a berkisar antara 0,05 -
$2,20 \mathrm{mg} / \mathrm{m}^{3}$ dengan rata-rata $0,426 \mathrm{mg} / \mathrm{m}^{3}$. Gambar $7 b$ merupakan sebaran konsentrasi klorofil-a bulan April yang berkisar antara $0,1-5,40 \mathrm{mg} / \mathrm{m}^{3}$ dengan rata-rata 1,060 $\mathrm{mg} / \mathrm{m}^{3}$. Gambar 7c merupakan sebaran klorofil-a bulan Mei yang berkisar antara $0,1-3,05 \mathrm{mg} / \mathrm{m}^{3}$ dengan rata-rata 0,605 $\mathrm{mg} / \mathrm{m}^{3}$. 


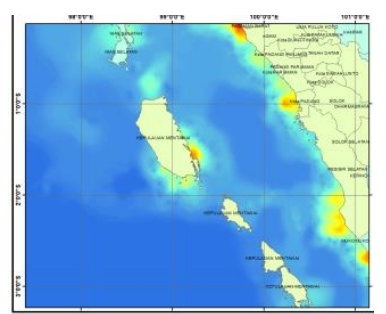

(a)

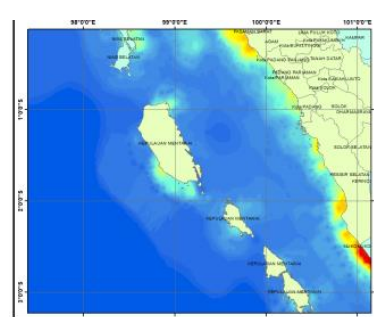

(b)

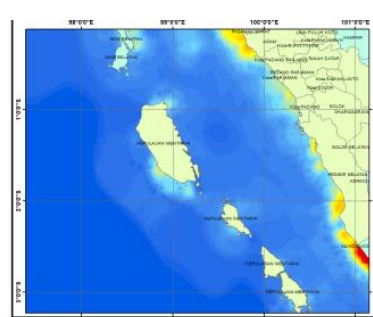

(c)

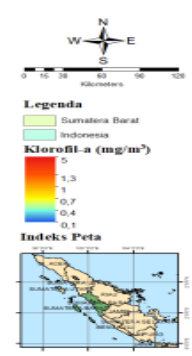

Gambar 7. Sebaran Klorofil-a Musim Peralihan I. (a) Sebaran Klorofil-a Bulan Maret, (b) Sebaran Klorofil-a Bulan April, (c) Sebaran Klorofil-a Bulan Mei.

Sebaran Konsentrasi Klorofil-a Musim Timur

Gambar 8 merupakan sebaran interpolasi konsentrasi klorofil-a pada Musim Timur (Juni-Agustus) 2018. Gambar 8a merupakan sebaran konsentrasi klorofil-a pada bulan Juni berkisar antara $0,1-3,25 \mathrm{mg} / \mathrm{m}^{3}$ dengan rata-rata 0,679

$\mathrm{mg} / \mathrm{m}^{3}$. Gambar $8 \mathrm{~b}$ merupakan sebaran konsentrasi klorofil-a bulan Juli yang berkisar antara $0,1-4,25 \mathrm{mg} / \mathrm{m}^{3}$ dengan rata-rata $0,731 \mathrm{mg} / \mathrm{m}^{3}$. Gambar $8 \mathrm{c}$ adalah sebaran klorofil-a bulan Agustus berkisar antara $0,05-4,30 \mathrm{mg} / \mathrm{m}^{3}$ dengan rata-rata $0,796 \mathrm{mg} / \mathrm{m}^{3}$.

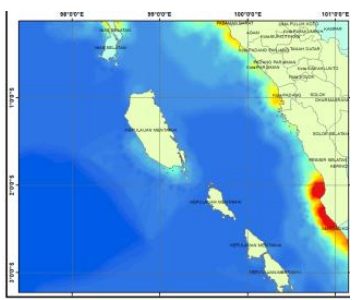

(a)

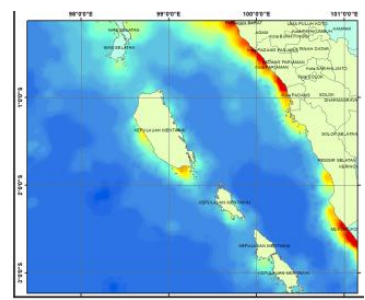

(b)

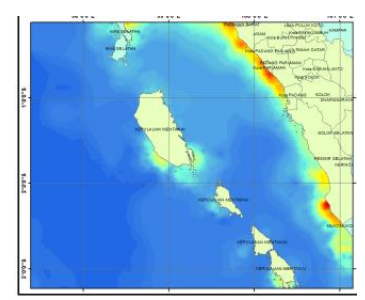

(c)

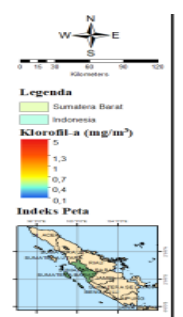
Bulan Juni, (b) Gambar 8. Sebaran Klorofil-a Musim Timur. (a) Sebaran Klorofil-a Bulan
Sebaran Klorofil-a Bulan Juli, (c) Sebaran Klorofil-a Bulan Agustus.

\section{Sebaran Konsentrasi Klorofil-a Musim Peralihan II}

Gambar 9 merupakan sebaran interpolasi konsentrasi klorofil-a pada Musim Peralihan II (September-November) 2018. Gambar 9a adalah sebaran konsentrasi klorofil-a pada bulan September yang berkisar antara 0,1 - 2,95

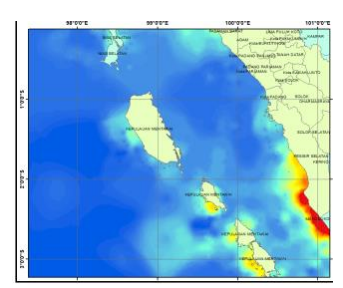

(a)

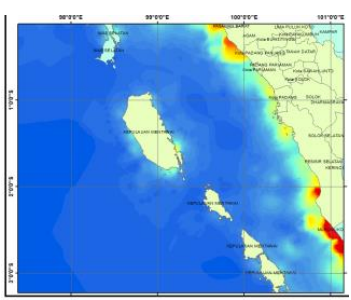

(b)

$\mathrm{mg} / \mathrm{m}^{3}$ dengan rata-rata $0,709 \mathrm{mg} / \mathrm{m}^{3}$ Gambar 9b merupakan sebaran klorofil-a bulan Oktober yang didapat dari citra berkisar antara $0,1-9,00 \mathrm{mg} / \mathrm{m}^{3}$ dengan rata-rata $1,503 \mathrm{mg} / \mathrm{m}^{3}$. Gambar $9 \mathrm{c}$ merupakan sebaran klorofil-a bulan November berkisar antara $0,1-10,20$ $\mathrm{mg} / \mathrm{m}^{3}$ dengan rata-rata $1,523 \mathrm{mg} / \mathrm{m}^{3}$.

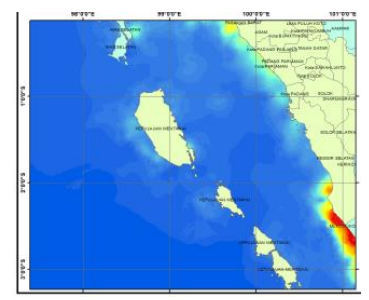

(c)

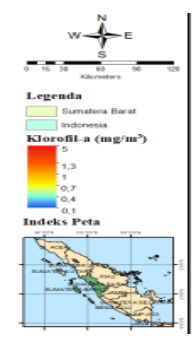

Gambar 9. Sebaran Klorofil-a Musim Peralihan II. (a) Sebaran Klorofil-a Bulan September, (b) Sebaran Klorofil-a Bulan Oktober, (c) Sebaran Klorofil-a Bulan November. 


\section{Analisis Hasil Tangkapan}

Hasil tangkapan ikan madidihang selama 1 tahun yang didaratkan di Pelabuhan Perikanan Samudera (PPS) Bungus dimana ikan yang ditangkap harus memiliki panjang $\geq 50 \mathrm{~cm}$ seperti yang disajikan pada Tabel 1. Hasil tangkapan yang didaratkan di PPS Bungus pada setiap musimnya cenderung tinggi. Tingginya hasil tangkapan pada setiap musim tersebut dipengaruhi oleh upaya penangkapan (effort) yang juga tinggi.

Pada Tabel 6 terlihat bahwa hasil tangkapan tertinggi terdapat pada bulan Oktober sebesar $60.610 \mathrm{~kg}$, jika ditinjau dari nilai CPUE nya, nilai CPUE pada bulan Oktober ini tergolong tertinggi dan sebanding dengan hasil tangkapan. jika ditinjau dari nilai CPUEnya, nilai CPUE pada Bulan Oktober ini tergolong tinggi dan sebanding dengan hasil tangkapannya yang tinggi. Sementara jika dilihat dari nilai CPUE terendah terdapat pada penangkapan bulan Maret yaitu sebesar 64,9693 kg/trip dengan jumlah hasil tangkapan yaitu $29.626 \mathrm{~kg}$. Apabila dilihat dari hasil tangkapan terendah terdapat pada bulan Juni dengan total tangkapan 18.080 $\mathrm{kg}$ dan nilai CPUEnya 92,7179 kg/trip. Jumlah hasil tangkapan total yellowfin tuna pada tahun 2018 dari Bulan Januari hingga Desember 2018 adalah sebesar $463.053 \mathrm{~kg}$.

Tabel 6. Hasil Tangkapan Yellowfin Tuna Tahun 2018

\begin{tabular}{cccccc}
\hline No & Bulan & Musim & Cacth $(\mathrm{kg})$ & Effort (trip) & CPUE (kg/trip) \\
\hline 1 & Januari & \multirow{2}{*}{ Barat } & 38.780 & 343 & 113,061 \\
2 & Februari & & 37.677 & 277 & 136,018 \\
3 & Maret & & 29.626 & 456 & 64,9693 \\
4 & April & Peralihan I & 38.259 & 317 & 120,691 \\
5 & Mei & & 36.525 & 333 & 109,685 \\
6 & Juni & & 18.080 & 195 & 92,7179 \\
7 & Juli & Timur & 38.193 & 547 & 69,8227 \\
8 & Agustus & & 35.547 & 244 & 145,684 \\
9 & September & & 48.353 & 340 & 142,215 \\
10 & Oktober & Peralihan II & 60.610 & 366 & 165,601 \\
11 & November & & 51.717 & 515 & 100,421 \\
12 & Desember & Barat & 29.686 & 245 & 121,167 \\
\hline \multicolumn{7}{r}{ Total } & & 463.053 & 4.178 & 1382,05 \\
\hline
\end{tabular}

\section{Hubungan Suhu Permukaan Laut dengan Hasil Tangkapan}

Berdasarkan sebaran SPL dan hasil tangkapan pada tahun 2018 nilai koefisien korelasi (r) adalah -0.69 dimana nilai $(\mathrm{r}) \leq-$ 0,6 yang menandakan korelasi antara kedua variabel erat, sedangkan koefisien determinasi $\left(\mathrm{R}^{2}\right)$ adalah $47,61 \%$, artinya masih ada pengaruh dari faktor lain sebesar $52,39 \%$.

\section{Hubungan Klorofil-a dengan Hasil Tangkapan}

Berdasarkan sebaran klorofil-a dan hasil tangkapan pada tahun 2018 nilai koefisien korelasi (r) adalah 0,65 dimana nilai $(\mathrm{r})<0,7$ yang menandakan lemahnya korelasi antara kedua variabel tersebut, sedangkan nilai koefisien determinasi $\left(\mathrm{R}^{2}\right)$ adalah $42,25 \%$ yang masih ada pengaruh dari faktor lain sebesar 57,75\%. 


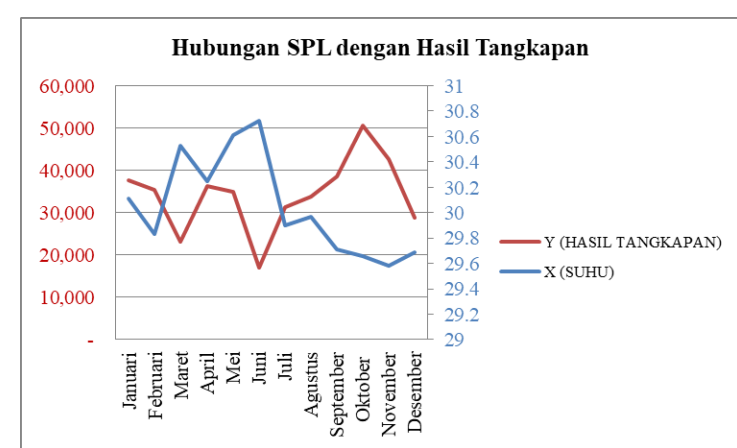

Gambar 10. Hubungan SPL dengan Hasil Tangkapan

\section{Zona Fishing Ground}

Zona fishing ground didasarkan pada sebaran SPL dan klorofil-a tahun 2018 yang disajikan pada Gambar 12 berdasarkan 4 musim yaitu Musim Barat, Musim Peralihan I, Musim Timur dan Musim Peralihan II dan menunjukkan kawasan penangkapan yellowfin tuna di

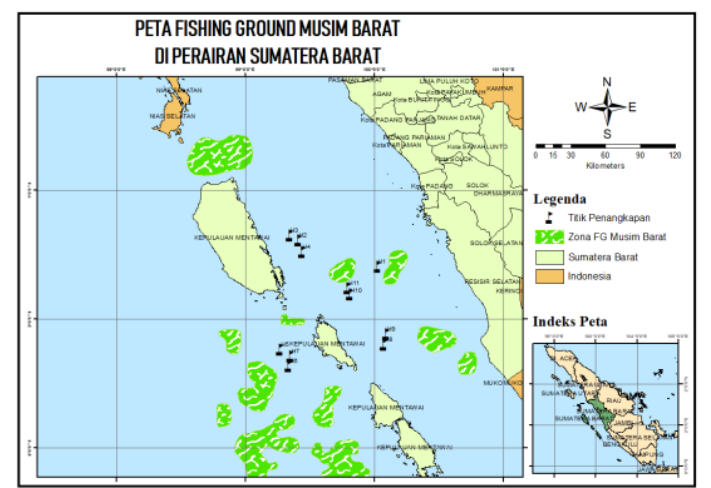

(a)

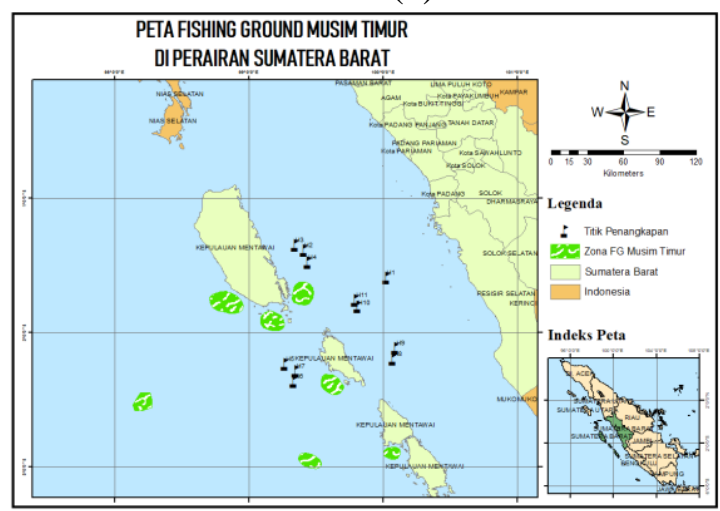

(c)

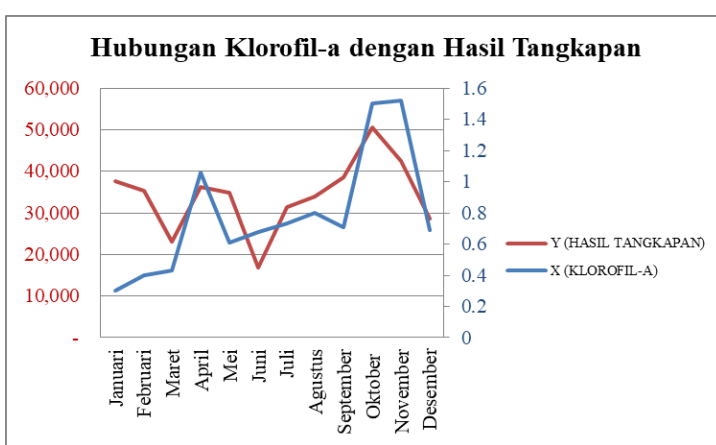

Gambar 11. Hubungan Klorofil-a dengan Hasil Tangkapan

perairan Sumatera Barat. Musim Barat dan Musim Peralihan II merupakan musim yang baik untuk melakukan penangkapan karena terdapat daerah potensial penangkapan yang lebih banyak dibandingkan dengan Musim Peralihan I dan Musim Timur hanya memiliki beberapa wilayah potensial penangkapan.

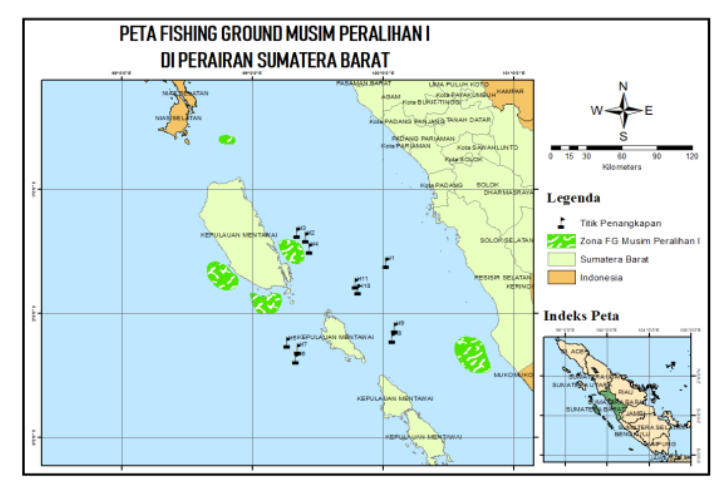

(b)

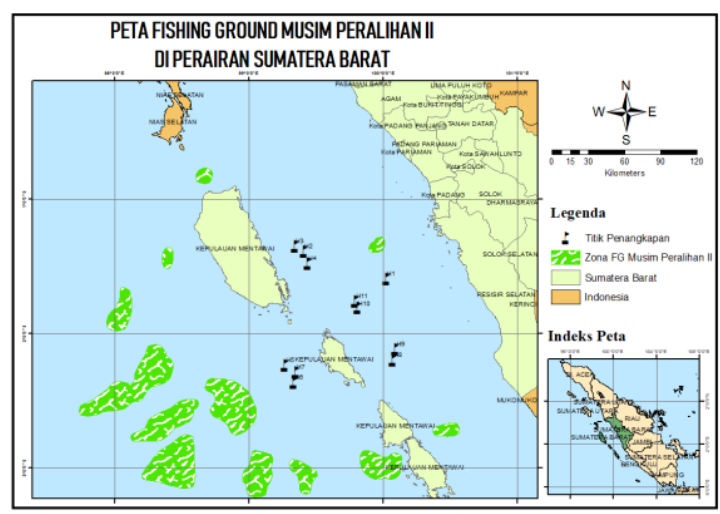

(d)

Gambar 12. Zona Fishing Ground Yellowfin Tuna Tahun 2018. (a) Zona Fishing Ground Yellowfin Tuna Musim Barat, (b) Zona Fishing Ground Yellowfin Tuna Musim Peralihan I, (c) Zona Fishing Ground Yellowfin Tuna Musim Timur, (d) Zona Fishing Ground Yellowfin Tuna Musim Peralihan II 
Jika dilihat dari nilai CPUE bulan terbaik untuk melakukan penangkapan yaitu Bulan Oktober (Musim Peralihan II) karena pada bulan tersebut nilai CPUE yang tertinggi dengan upaya penangkapan yang lebih maksimal. Bulan penangkapan yang kurang baik berada pada Bulan Maret (Musim Peralihan I) karena memiliki nilai CPUE yang paling rendah dibandingkan dengan bulan-bulan lainnya di tahun 2018 . Kurangnya daerah penangkapan yang potensial pada bulan Maret ini akan mempengaruhi upaya penangkapan sehingga apabila ingin mendapatkan hasil tangkapan yang lebih baik maka upaya penangkapan harus ditingkatkan, hal ini juga akan berakibat pada waktu dan biaya yang akan semakin meningkat.

\section{KESIMPULAN DAN SARAN}

Produktivitas hasil tangkapan yellowfin tuna tertinggi pada tahun 2018 yaitu bulan Oktober (Musim Peralihan II), sedangkan hasil tangkapan terendah berada pada bulan Juni (Musim Timur). Berdasarkan nilai CPUE, bulan Oktober dapat dikategorikan sebagai bulan penangkapan yang paling baik. Korelasi antara SPL dengan hasil tangkapan yellowfin tuna tahun 2018 menunjukkan nilai korelasi negatif yang bersifat berlawanan, sedangkan korelasi antara klorofil-a dengan hasil tangkapan menunjukkan korelasi yang lemah.

Untuk penelitian selanjutnya, perlu dilakukan penelitian lanjutan tentang karakteristik oseanografi lainnya seperti upwelling, thermal front, kedalaman dan lainnya yang memungkinkan mempengaruhi keberadaan ikan yellowfin tuna di perairan Sumatera Barat guna menentukan daerah penangkapan yang lebih akurat sehingga akan menghasilkan hasil tangkapan yang lebih baik.

\section{DAFTAR PUSTAKA}

1. Basuma, T. (2009). Penentuan Daerah Penangkapan Ikan Tongkol Berdasarkan Pendekatan Suhu Permukaan Laut dan Hasil Tangkapan di Perairan Binuangeun Banten [Skripsi]. Bogor: Departemen Pemanfaatan Sumberdaya Perikanan, Fakultas Perikanan dan Ilmu Kelautan, Institut Pertanian Bogor.

2. Hutabarat, S. dan S. M. Evans. (2006). Pengantar Oseanografi. Jakarta: UI-Press. 159.

3. Hela, I. dan T. Laevastu, (1993). Fisheries Oceanography. London: Fishing News Book Ltd. 238.

4. Ilahude, A. G. (1997). Sebaran suhu, salinitas, sigma-T dan zat hara perairan Laut Cina Selatan. Dalam: Suyarso (ed.). Atlas oseanologi laut cina selatan. Puslitbang Oseanologi-LIPI. Jakarta. 25-34.

5. Kantun, W., A. Mallawa dan N. L. Rapi. (2014). Stuktur Ukuran dan Jumlah Tangkapan Tuna Madidihang (Thunnus albacares) Menurut Waktu Penangkapan dan Kedalaman Di Perairan Majene Selat Makassar. Jurnal Saintek Perikanan. 9 (2) : 39-48.

6. Lind, D. A., D. M. Robert dan W. G. Marchal. (2000). Basic Statistics For Business and Economics. McGraw-Hill Companies. Singapore.

7. Mubarak, A. Nurhuda dan M. Galib. (2015). Analisis Suhu Permukaan Laut Selat Malaka. Prosiding Seminar Nasional "Pelestarian Lingkungan dan Mitigasi Bencana" Pekanbaru.

8. Noija, D., S. Martasuganda., B. Murdiyanto dan A. A. Taurusman. (2014). Potensi dan Tingkat Pemanfaatan Sumberdaya Ikan Demersal di Perairan Pulau Ambon-Provinsi Maluku. Jurnal Teknologi Perikanan dan Kelautan. Institut Pertanian Bogor. Bogor. 
9. Nontji, A. (2007). Laut Nusantara. Edisi Revisi, Cetakan ke-5. Djambatan. Jakarta, 300.

10. Rasyid J. dan Ibrahim. (2013). Spermonde Kondisi Oseanografi Versus Ikan Pelagis. Masagena Press. Makassar.

11. Triatmodjo, B. (2008). Pelabuhan. Yogyakarta: Beta Offset.

12. Walpole, E. (1995). Pengantar Statistik. Jakarta: Gramedia Pustaka Utama. 